\title{
HOW TO DEVELOP THE STANDARDIZED INSTRUMENTS OF MULTIPLE INTELLIGENCES IN ELEMENTARY SCHOOL: A QUALITATIVE-DESCRIPTIVE APPROACH
}

\author{
Tria Mardiana ${ }^{1}$, Indiati ${ }^{2}$ \\ ${ }^{1}$ Pendidikan Guru Sekolah Dasar, Fakultas Keguruan dan Ilmu Pendidikan, Universitas \\ Muhammadiyah Magelang, Indonesia \\ ${ }^{2}$ Bimbingan dan Konseling, Fakultas Keguruan dan Ilmu Pendidikan, Universitas \\ Muhammadiyah Magelang, Indonesia \\ 1 triamardiana@ummgl.ac.id, ${ }^{2}$ indiati@ummgl.ac.id
}

Citation: Mardiana, T., \& Indiati. (2020). How to develop the standardized instruments of multiple intelligences in elementary school: a qualitative-descriptive approach. Indonesian Journal of Elementary Teachers Education, 1 (1), 27-38.

Received: 01-14-2020 Accepted: 05-30-2020 Published: 05-31-2020

\begin{abstract}
It was rarely the academicians, and practitioners knew how to make the standardized instruments to analyze the student's multiple intelligences. The purpose of this study was to describe the development of a standardized instrument of multiple intelligences for children in elementary school. The research method used was descriptive qualitative. In qualitative research, the research instrument was the researcher himself. The research instrument was not external or objective, but internal or subjective, namely the researcher himself without using tests, questionnaires, or experiments. Therefore the direct presence of researchers was a necessity in qualitative research. The data collection techniques used were observation and documentation. The results obtained in this study were to identify multiple intelligences in 712 years old children, we could use standardized instruments based on the classification of children's multiple intelligences. To analyze the development of multiple intelligences of 7-12 years old children, we could use the major theory of Gardner and Armstrong. The development of standard instruments used to measure multiple intelligences of 7-12 years old children, we could use 13 steps of Jamaris theory. This development step unravels the theory, determines the basis, then turns it into a standardized instrument that can be used to measure the type of multiple intelligences in 7-12 years old children. How to use the standardized instruments and its recommendations for teachers are discussed.
\end{abstract}

Keywords:multiple intelligences; standardized instrument; development 


\section{INTRODUCTION}

Elementary School is a basic educational institution whose students are aged between 7-12 years and have the characteristic of always being curious. In general, elementary students need a teacher as a guide who can be a role model while in school. The teacher provides several types of subjects with competencies that have been specified in Permendiknas Number 22 of 2006 concerning content standards (Desstya, 2015). In order to educate the life of the nation, professional teachers are needed. The teacher is not just teaching and providing course material, but a teacher must be a guide, model trainer, or role model of creativity and also renewal or innovator for students. (Pauziah, 2017). To maximize the ability of teachers to understand student competencies, understanding of student intelligence is also needed.

To date, education in Indonesia assesses that human intelligence is too narrow; humans are considered only to have one measurable intelligence called logical-mathematical intelligence, while the tool used to measure this intelligence is an IQ test (Rohmah, 2016). It was found in various studies that intelligence has more than one kind. The diversity of intelligences is often called Multiple Intelligences. According to the theory of multiple intelligences, all humans have eight kinds of intelligence and then develop again into nine different intelligences. By knowing the intelligence, it is important for a teacher to recognize the different characteristics of each student (Wahyudi \& Alafiah, 2016). From the reality of a child, intelligence diversity has made us aware as parents and educators, that each child is born smart with their potential (Kusniati, 2016).

Gardner said that "Intelligence is the ability to solve problems, or to create products that are valued within one or more cultural" (Gardner, 1983). According to Gardner, one's intelligence is not measured from the results of standard psychological tests, but it can be seen from one's habit of solving his own problems (problem-solving) and one's habits of creating new products that have cultural values (creativity). This statement is indicate that Gardner does not categorize intelligence from only one type, but many types. Gardner's multiple intelligences theory does not parse human intelligence to a single number determined by an intelligence quotient test (Phillips, 2010).

In learning activities, if the learning pattern follows the learning style, the results of the child's material understanding will be more significant. Multiple intelligence-based learning differs from other approaches (Anggreini \& Dewiyanti, 2015). Learning with multiple intelligences approach is an effort to provide learning experiences that are designed in harmony with the needs, style of students' cognition, especially relevant with the strength of each student's intelligence type. The multiple intelligences stimulation learning approach assumes that every child is smart, but their intelligence varies (Legowo, 2017). Gardner proposed that "The eight identified intelligence include linguistic intelligence, logicalmathematical intelligence, spatial intelligence, musical intelligence, bodily-kinesthetic intelligence, naturalistic intelligence, interpersonal intelligence, and intrapersonal intelligence" (Gardner, 1999).

One of the main keys of multiple intelligences is that intelligence usually works together in complex ways (Zulfairanatama \& Hadi, 2013). However, to begin learning activities based on the diversity of students' intelligence, it needs to be initiated through tests with standardized instruments of multiple intelligences. The standardized instrument of multiple intelligences is a tool that can help the teacher in analyzing the student intelligence type so that the teacher able to determine any teaching preparation that is tailored to the child's needs. The need for high intelligence analysis to make it easier to determine the concept of learning in the classroom became the main basis in the development of a 
standardized instrument of multiple intelligences in this study. Problems that can be identified related to the development of multiple intelligence instruments are: (1) how to identify multiple intelligence in 7-12 years, old children? (2) what concepts, principles and theories can be used to analyze multiple intelligence development 7-12 years old children? Furthermore, (3) how to develop standardized instruments that can be used to measure the multiple intelligence of 7-12 years old children? So that the analysis of children's multiple intelligence development can be done accurately and can be used as a basis for taking various actions that are appropriate to the child's developmental needs, especially in the preparation of the concept of learning activities in the classroom.

\section{RESEARCH METHOD}

\section{Research Design}

In order to answer the research question, the qualitative-descriptive research design was conducted in our study. This work was a part of a mini-research from our research and development process. In this part, we were conducted research to describe how to develop standardized instruments about multiple intelligences.

\section{Data Source}

The multiple intelligences concept, principles, and theory were the data source of our study. Furthermore, the development of standardized instruments was an object of this study.

\section{Data Collection}

The data were collected by observation and documentation. Researchers collected various sources regarding multiple intelligence in 7-12 years old children. The sources consist of the main sources and other related reference sources as supporting data results.

\section{Data Analysis}

The data were analyzed qualitatively direct after the data collected. The processes of the data analysis were conducted by the following steps: collecting the data, presenting the data, reducing the data, and then made a conclusion/verification for the analysis process.

\section{RESULTS AND DISCUSSION}

The activity assessment often used to measure the child's multiple intelligence. Activities assessment is an instrument to measure and assess activities (Jamaris, 2009). The standardized instrument of multiple intelligences is needed for assessing multiple intelligences (Jamaris, 2014). There are processes of the development of standardized instruments presented in Figure 1 (Jamaris, 2009).

In the first stage, The theory analysis conducted to identify the variable to be measured. In the second stage, based on the result of theory analysis, the Theory Synthesis is formulated as the basis to formulate the construct the variable to be measured. In the third stage, the dimensions and indicators of the variables to be measured are developed. In the fourth stage, it is necessary to determine the magnitude of the parameter that moves in a continuum from one pole to the opposite pole, such as from low to high, from negative to positive, from authoritarian to democratic, from dependent to independent. In the fifth stage, the preparation of the assessment instrument guidelines, followed by the sixth step, which is to draft the assessment instrument.

In the seventh stage, after the instrument concept is considered theoretically valid or conceptually, the limited instrument is carried out for field testing. In the eighth stage, 
instrument testing is part of the empirical validation process. In this trial, the instrument was given to a number of respondents who had the same or equivalent characteristics as the target population characteristics of the assessment instrument.

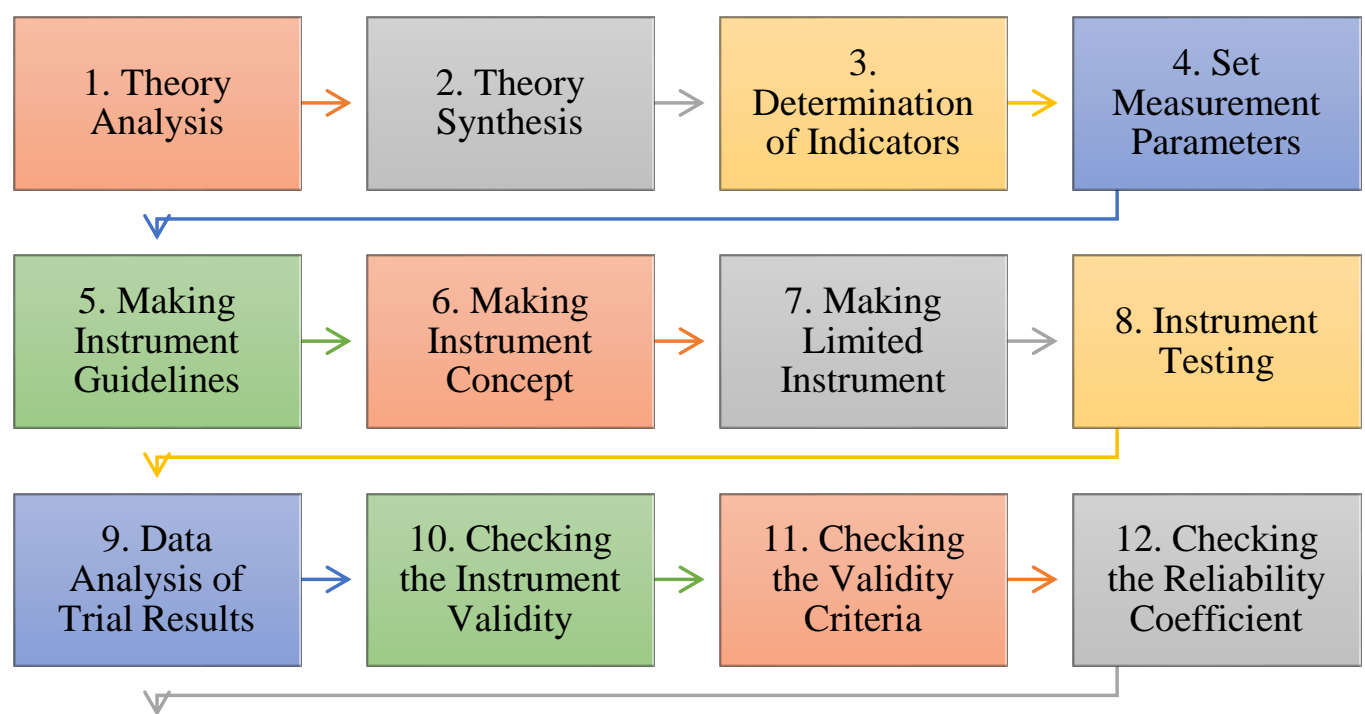

13. Final

Instrument

Assembly

Figure 1. The Processes of Multiple Intelligences Instrument Development (Jamaris, 2009)

In the ninth stage, an analysis of the instrument trial results was conducted to determine the instrument's validity. Validity testing must use internal criteria, the instrument itself, as a unity that is used as a criterion. While the external criteria, namely the suitability of the instrument trials, results with the measuring results of certain instruments in accordance with the instruments made. In the tenth stage, based on the instrument validity criteria, a conclusion can be reached regarding whether or not the instrument points are valid. In the eleventh stage, starting from item analysis, invalid items are issued or corrected for retrying, while valid items are reassembled into an instrument set to review the validity of the content based on the instrument guidelines. In the twelfth step, the reliability coefficient of the range $0-1$ is then calculated to indicate the magnitude of the quality or consistency of the instrument's measurement results. If the reliability coefficient is high, it will have a good impact on the quality of the instrument. The limits of reliability coefficient that are considered feasible depend on the precision desired by the instrument developer. At the last stage, the assembly of valid instrument items to be made the final instrument.

The thirteen stages are carried out in order to develop instruments that have good quality and accuracy of results. The stages in Figure 1 become the basis for the development of a standardized instrument of multiple intelligences of children in elementary school. Based on the standard instrumentalized development steps presented in Figure 1, researchers have presented the results of the details in Figure 2.

Figure 2 shows the results of the research that have been detailed. The results are obtained by observing student learning activities at the elementary level, as well as documenting theoretical sources regarding the theory of children's multiple intelligences. The 
Indonesian Journal of Elementary Teachers Education (IJETE)

p-ISSN: 2615-2606 \& e-ISSN: 2615-7853

Volume 1, Number 1, May 2020

https://journal.uniku.ac.id/index.php/ijete

theory obtained is specific to the level of children's development of 7-12 years old. This age is the standard age in Indonesia at the level of education for elementary schools.

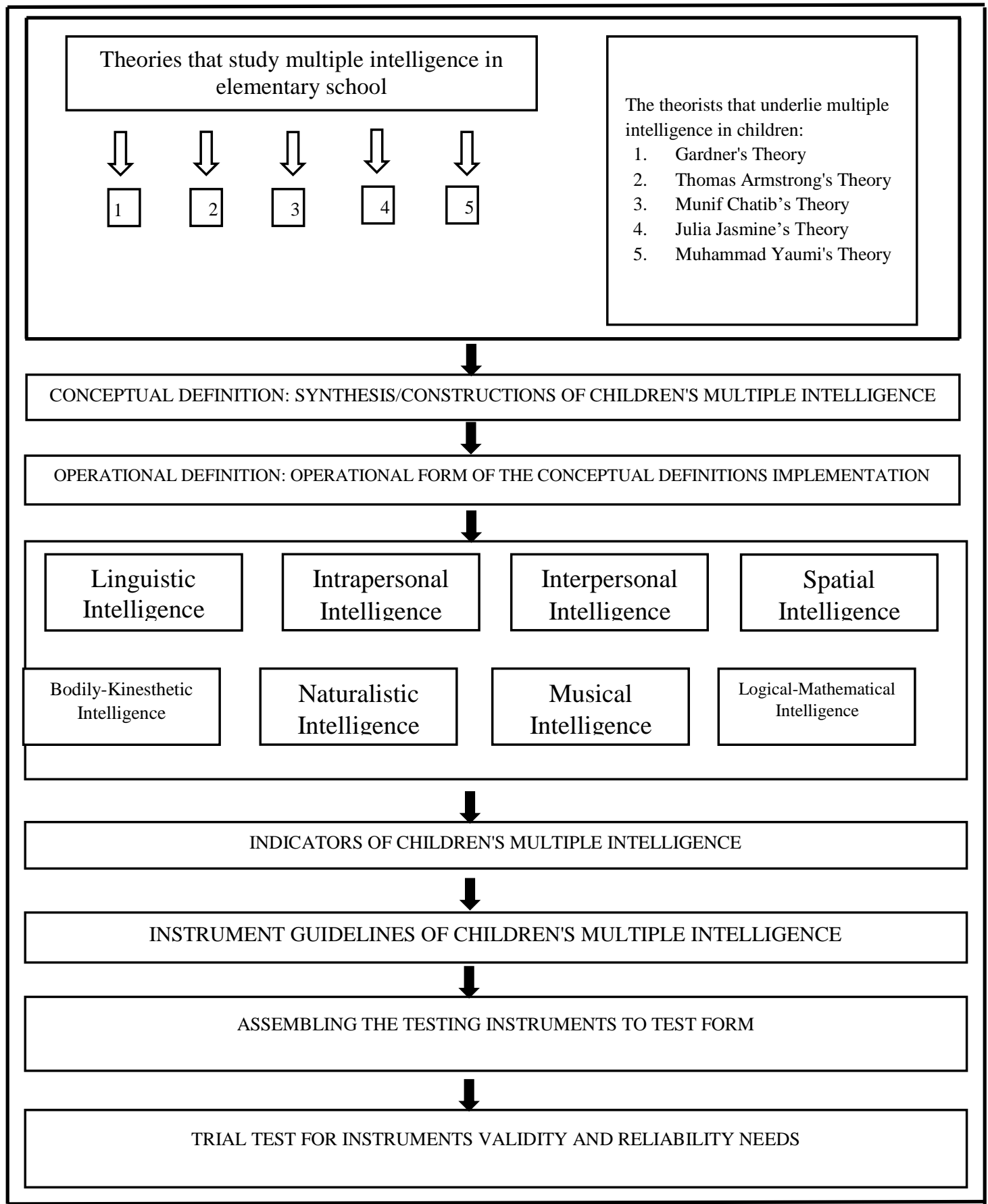

Figure 2. Basic Scheme for Development of Standard Instrument for Multiple Intelligences in Elementary School Children (7-12 Years)

In the first stage, analysis of theories relating to the grouping of multiple intelligences in children obtained five theories, namely Gardner's theory, Thomas Armstrong's theory, 
Munif Chatib's theory, Julia Jasmine's theory, and Muhammad Yaumi's theory. The main source of reference theory was from Gardner's theory and Thomas Armstrong's theory. Five theories obtained were then synthesized this synthesis process being the second stage. Based on the analysis of these theories, a synthesis of theories was formulated, which became the basis in formulating the construct of the variable to be measured. The variable measured in this study was multiple intelligence in children. The main theories regarding children's multiple intelligences consisting of 8 types of intelligence, namely Linguistic intelligence, Logical-Mathematical intelligence, Visual-Spatial intelligence, Kinesthetic intelligence, Musical intelligence, Interpersonal intelligence, Intrapersonal intelligence, and Naturalist intelligence. Theories regarding the eight types of multiple intelligences explained in more specific and detailed terms. This stage enters the third stage in the development of standardized instruments to measure the types of multiple intelligences. Based on the construct, then the dimensions and indicators of the measured variables are developed.

Variables obtained from Howard Gardner, Linguistics: information analysis, producing works from oral and written. Mathematical logic: able to solve abstract problems. Visual-spatial: recognize images. Musical: produce sound, remember the sound, interpret sound. Naturalist: plant classification, animal classification, weather determination. Kinesthetic: bodybuilding. Interpersonal: understanding other people. Intrapersonal: understanding yourself.

Variables obtained from Munif Chatib, Linguistics: word expression. Mathematical logic: the ability to count, measure, and complete numerical operations. Spatial visual: imagination exploration. Musical: sensitivity to tone, melody, and rhythm. Naturalist: like the environment. Kinesthetic: direct practice motion activities. Interpersonal: understanding and interaction with others. Intrapersonal: accurate understanding and perception with self.

Variable obtained from Thomas Armstrong, Linguistics: able to appropriately use words. Mathematical logic: effectively using numbers. Visual-spatial: sensitive to visual form. Musical: feel, differentiate, and express musical forms. Naturalist: recognize and classify flora and fauna. Kinesthetic: expression of gestures. Interpersonal: understanding the moods of others. Intrapersonal: self-knowledge.

Variable obtained from Julia Jasmine, Linguistics: excellent listening ability. Mathematical logic: good scientific ability. Visual-spatial: easy to learn through image presentation. Musical: sensitive to sound or sound. Kinesthetic: responds to information through physical exercise. Interpersonal: understand and interact well with others. Intrapersonal: deep awareness of self.

Variables obtained from Muhammad Yaumi, Linguistics: expression through both oral and written words. Mathematical logic: smart with numbers and reasoning. Visualspatial: able to understand images and shapes well. Musical: able to hear, recognize, remember, and even manipulate musical patterns. Naturalist: Enjoy observation and discovery of natural phenomena. Kinesthetic: uses all parts of the body to solve problems or make things. Interpersonal: interaction with other people around him.

In the fourth stage, it was necessary to determine the magnitude or parameter that moves in a continuum from one pole to the opposite pole, such as from low to high, from negative to positive, from authoritarian to democratic, from dependent to independent. Determination of the measurement parameters in research related to children aged 6-12 years. This period is sometimes referred to as middle childhood or latency, a time for new challenges. The cognitive power to think of many factors simultaneously gives the ability of school-age children to evaluate themselves and feel the evaluation of their peers. It can be concluded that self-esteem is a central problem for school-age children (Arvin et al, 2000). 
Based on Piaget's theory, children at elementary school age also enter a concrete operational period, where they learn through concrete things before understanding various abstract things. As a measurement of product development, the instrument developed only contains 2 alternative answers, namely Yes and No, assuming that when students answer Yes it is an appropriate condition, and the answer No constitutes a mismatch of the intended conditions.

In the fifth stage, the preparation of the assessment instrument guidelines. The instrument guidelines in this study refers to the concept of Multiple Intelligences which has been described by 5 figures, namely Howard Gardner, Thomas Armstrong, Munif Chatib, Julia Jasmine, and Muhammad Yaumi. The instrument guidelines developed in this study were as follows, linguistic intelligence consists of, word expression, producing works from oral and written. Logical-mathematical intelligence consists of, the abilities related to counting, measuring, and completing number operations. Spatial-visual intelligence consists of, sensitivity to visual form. Kinesthetic intelligence consists of, expressions of gestures. Musical intelligence consists of, sensitivity to tone, melody, and rhythm. Interpersonal intelligence consists of, understanding and interaction with others. Intrapersonal intelligence consists of self-understanding, understanding, and perception. Naturalist intelligence consists of, pleasure for the environment.

In the sixth step that was making the concept of assessment instruments. The concept of the developed instrument was arranged in the form of tables.

Table 1. List of Linguistic Intelligence Statements

\begin{tabular}{|c|c|c|}
\hline \multirow[t]{2}{*}{ No } & \multirow[t]{2}{*}{ Statements } & Answer \\
\hline & & Yes \\
\hline 1 & I like to chat with others & \\
\hline 2 & I like to write many thing (e.g. simple story, poem and diary) & \\
\hline 3 & I like reading a short storypendek & \\
\hline 4 & I am easy to memorize a name, places, date, and etc. & \\
\hline 5 & I like to reading a book in the free time & \\
\hline 6 & Books are important for me & \\
\hline 7 & I like to play crossword puzzle & \\
\hline 8 & I like Indonesian language subject rather than others subject & \\
\hline 9 & I like funny poem and poet, and word games & \\
\hline 10 & I like word, story, and radio & \\
\hline 11 & I am easy to explain something to others & \\
\hline 12 & I could manage something rapidly, that was others says to me & \\
\hline
\end{tabular}

Table 2. List of Logical-Mathematical Intelligence Statements

\begin{tabular}{lll}
\hline No & \multicolumn{1}{c}{ Statements } & \multicolumn{2}{c}{ Answer } \\
\cline { 2 - 2 } $\mathbf{1}$ & I am able to count by rote & No \\
\hline $\mathbf{2}$ & I am able to count by rote easily & \\
$\mathbf{3}$ & I like mathematics subject \\
\hline $\mathbf{4}$ & I am easy to remember mathematics procedures \\
\hline $\mathbf{5}$ & I am able to describe something in detail \\
\hline $\mathbf{6}$ & $\begin{array}{l}\text { I am often ask to others when I could not understand } \\
\text { something }\end{array}$ \\
\hline $\mathbf{7}$ & I like to do an experiment \\
\hline
\end{tabular}


Tria Mardiana \& Indiati

HOW TO DEVELOP THE STANDARDIZED INSTRUMENTS OF MULTIPLE

INTELLIGENCES IN ELEMENTARY SCHOOL: A QUALITATIVE-DESCRIPTIVE

APPROACH

\begin{tabular}{|c|c|c|}
\hline \multirow[t]{2}{*}{ No } & \multirow[t]{2}{*}{ Statements } & Answer \\
\hline & & Yes \\
\hline 8 & I am able to arrange things in a group & \\
\hline 9 & I like answer a question with reasoning & \\
\hline
\end{tabular}

Table 3. List of Visual-spatial Intelligence Statements

\begin{tabular}{lll}
\hline No & \multicolumn{1}{c}{ Statements } & \multicolumn{2}{c}{ Answer } \\
\cline { 2 - 2 } $\mathbf{1}$ & I like to drawing subject & No \\
\hline $\mathbf{2}$ & I like to draw \\
\hline $\mathbf{3}$ & I am able to draw an object \\
\hline $\mathbf{4}$ & I could imagine a picture clearly \\
\hline $\mathbf{5}$ & I am able to distinguish colors correctly \\
\hline $\mathbf{6}$ & I like to take a pictures with camera \\
\hline $\mathbf{7}$ & I could find a way/new place in unknown location \\
\hline $\mathbf{8}$ & I'd prefer to read a book with pictures \\
\hline $\mathbf{9}$ & I like to go to a museum \\
\hline $\mathbf{1 0}$ & I am able to understand a map or graph quickly \\
\hline $\mathbf{1 1}$ & I am able to understand a sketch or a direction \\
\hline
\end{tabular}

Table 4. List of Kinesthetic Intelligence Statements

\begin{tabular}{|c|c|c|}
\hline \multirow[t]{2}{*}{ No } & \multirow[t]{2}{*}{ Statements } & Answer \\
\hline & & Yes \\
\hline 1 & I like to do sport & \\
\hline 2 & I like to run & \\
\hline 3 & I feel curious about the taste, shape of a thing & \\
\hline 4 & I like dancing subject & \\
\hline 5 & I hive daily routine to do sport & \\
\hline 6 & I like to learn outside the classroom & \\
\hline 7 & I feel difficult to keep in no activity in a long time & \\
\hline 8 & I like to make a handicraft & \\
\hline 9 & I like to strolling activity & \\
\hline 10 & I like to play outside rather than inside a room & \\
\hline 11 & My hand always moving when talking with others & \\
\hline 12 & I enjoy a challenging vehicle & \\
\hline 13 & I like with subject that give me a chance to do something & \\
\hline 14 & I am strong enough to do sport activities & \\
\hline
\end{tabular}

Table 5. List of Intrapersonal Intelligence Statements

\begin{tabular}{lll}
\hline No & \multicolumn{1}{c}{ Statements } & \multicolumn{2}{c}{ Answer } \\
\cline { 3 - 3 } & & Yes \\
\hline $\mathbf{1}$ & I am could understand my self & \\
\hline $\mathbf{2}$ & I like to do something I love by self & \\
\hline $\mathbf{3}$ & I always confident to solve an examination test \\
\hline $\mathbf{4}$ & I am not easy to affected by others & \\
\hline $\mathbf{5}$ & I am an independent person & \\
\hline
\end{tabular}


Indonesian Journal of Elementary Teachers Education (IJETE)

p-ISSN: 2615-2606 \& e-ISSN: 2615-7853

Volume 1, Number 1, May 2020

https://journal.uniku.ac.id/index.php/ijete

$6 \quad$ I like to do something on my way

7 I always have strong argument

Table 6. List of Interpersonal Intelligence Statements

\begin{tabular}{|c|c|c|}
\hline \multirow[t]{2}{*}{ No } & \multirow[t]{2}{*}{ Statements } & Answer \\
\hline & & Yes \\
\hline 1 & I often pointed as a leader & \\
\hline 2 & I like to talk with others & \\
\hline 3 & I have a lot of friends & \\
\hline 4 & I could break up my friend when they were fighting & \\
\hline 5 & I like to collaborate with others & \\
\hline 6 & I like an event with a lot of people & \\
\hline 7 & I am brave to acquainted with new people & \\
\hline 8 & I like to learn in a group & \\
\hline 9 & I like interviewing people & \\
\hline 10 & I like to have a discussion and telling a story with others & \\
\hline
\end{tabular}

Table 7. List of Musical Intelligence Statements

\begin{tabular}{|c|c|c|}
\hline \multirow[t]{2}{*}{ No } & \multirow[t]{2}{*}{ Statements } & Answer \\
\hline & & Yes \\
\hline 1 & I like to sing a song & \\
\hline 2 & I could sing a song & \\
\hline 3 & I like a subject related to music & \\
\hline 4 & I like to do something related to music & \\
\hline 5 & I could remember the tone of music & \\
\hline 6 & I could recognize a tone & \\
\hline 7 & I like to singing & \\
\hline 8 & I like to make a clap with my hand and feet & \\
\hline 9 & I often make a whistle & \\
\hline 10 & I am happy to listen a music & \\
\hline 11 & $\begin{array}{l}\text { I am able to recognize kind of music instrument when } \\
\text { listening a music }\end{array}$ & \\
\hline
\end{tabular}

Table 8. List of Naturalist Intelligence Statements

\begin{tabular}{|c|c|c|}
\hline \multirow[t]{2}{*}{ No } & \multirow[t]{2}{*}{ Statements } & Answer \\
\hline & & Yes \\
\hline 1 & I like to learn through observation & \\
\hline 2 & I like to caring for animals & \\
\hline 3 & I have a pet & \\
\hline 4 & I like to go to zoo & \\
\hline 5 & I like to do scout & \\
\hline 6 & I like to camp & \\
\hline 7 & $\begin{array}{l}\text { I am glad when teacher use plant as media in learning } \\
\text { activities }\end{array}$ & \\
\hline 8 & I like to planting and watering & \\
\hline 9 & I do not like air pollution & \\
\hline
\end{tabular}




\section{I like to care the environment \\ 11 I like TV program about nature \\ 12 I like to do a community service}

In the seventh stage, after the instrument concept was considered valid both theoretically or conceptually, the instrument was tested in the limited subject. According to the results of the trial test, various inputs were found for revision. In the eighth to thirteenth stages were a series of stages of validation, testing, revision, then determining the validity of questions. In the validation stage, it involves experts to checked the developed instruments. If weaknesses were found, we used to repaired and evaluated materials. Regarding the trial stage, this was also part of the empirical validation process. In this trial test, the instrument was given to a number of respondents who had the same or equivalent characteristics as the target population characteristics of the assessment instrument. The respondents used were elementary school students.

After conducting trials test, if weakness were found, revisions were made to improve the instruments developed. In instrument development, the instrument reliability coefficient using the range $0-1$. That was a quantity that indicates the amount of quality or consistency of the instrument's measurement results. If the reliability coefficient was high, it would have a good impact on the quality of the instrument. The limits of reliability coefficient that are considered feasible depend on the precision desired by the instrument developer. These stages then become the basis for producing standard final product instruments to analyze multiple intelligences in children aged 7-12 years.

\section{CONCLUSION AND RECOMMENDATION}

The results obtained in this study were: (1) To identify multiple intelligence of 7-12 years old children, we can used a standardized instrument based on the classification of children's multiple intelligence; (2) To analyze the development of multiple intelligences 712 years old children, we can use the major theory of Gardner and Armstrong; (3) The development of standardized instruments used to measure multiple intelligence of 7-12 years old children, we can use 13 steps of Jamaris theory. This development step unravels the theory, determines the basis, then turns it into a standardized instrument that can be used to measure the type of multiple intelligence in 7-12 years old children.

Standardized instruments are used at the beginning of the new school academic year, it is before the process of learning activities begins. For first-grade, we can involve parents' help to fill it. It is because to anticipate children's fluency in reading. Implementation of the use of these standardized instruments can be done several weeks before the new school academic year begins. If the distance is long enough, the teacher can freely use the results of standardized instruments using. In its application, the already standardized instrument is given to students, then recaps which type of intelligence is most prominent.

The use of standardized instruments in mapping the types of children's intelligence can help teachers determine the methods or models of learning that relevant to the child's needs. For example, if in a class a prominent type of Visual-spatial Intelligence emerges, the teacher can maximize learning models that support that type of intelligence. 


\section{REFERENCES}

Anggreini, D., \& Dewiyanti, W. (2015). Studi penerapan multiple intelegences pada materi pokok garis dan sudut. SEMINAR NASIONAL MATEMATIKA DAN PENDIDIKAN MATEMATIKA UNY 2015, 291-298.

Arvin, Behrman Kliegman., et al. (2000). Ilmu kesehatan anak Nelson edisi 15 volume 1. Jakarta: Penerbit Buku Kedokteran EGC.

Desstya, A. (2015). Penguatan karakter siswa sekolah dasar melalui pembelajaran ipa. Prosiding Seminar Nasional dan Call for Papers Pendidikan Guru Sekolah Dasar UMS 2015, 69-75.

Gardner, H. (1983). Frames of mind: the theory of multiple intelligences. New York: Basic Books.

Gardner, H. (1999). The disciplined mind: what all students should understand. New York: Simon \& Schuster.

Jamaris, M. (2009) Kesulitan belajar: perspektif, asesmen, dan penanggulangannya. Jakarta: Yayasan Penamas Murni.

Jamaris, M. (2014). Pengembangan instrumen baku kecerdasan jamak anak usia dini. Jurnal Parameter, 25 (2), 123-136.

Kusniati, E. (2016). Strategi pembelajaran berbasis multiple intelligences. NUANSA, 9 (2), $167-178$.

Legowo, E. (2017). Model pembelajaran berbasis penstimulasian multiple intelligences siswa. Jurnal Kajian Bimbingan dan Konseling, 2 (1), 1-9.

Pauziah, R. (2017). Penerapan metode diskusi untuk meningkatkan aktivitas siswa pada pembelajaran menirukan pembacaan pantun anak di kelas IV SD Negeri 19 Kepahiang Kabupaten Kepahiang Provinsi Bengkulu. Jurnal Ilmiah Pendidikan Guru Sekolah Dasar, 10 (1), 42-46.

Phillips, H. (2010). Multiple Intelligences: theory and application. A Journal of the College of Education \& Health Professions, 11 (1), 4-11.

Rohmah, S. (2016). Strategi pembelajaran pendidikan agama islam berbasis kecerdasan majemuk (multiple intelegences). Misykat al-Anwar, 1 (2), 193-209.

Wahyudi, D., \& Alafiah, T. (2016). Studi penerapan strategi pembelajaran berbasis multiple intelligences dalam mata pelajaran pendidikan agama Islam. Mudarrisa: Jurnal Kajian Pendidikan Islam, 8 (2), 255-282. doi: 10.18326/mudarrisa.v8i2. 
Tria Mardiana \& Indiati

HOW TO DEVELOP THE STANDARDIZED INSTRUMENTS OF MULTIPLE

INTELLIGENCES IN ELEMENTARY SCHOOL: A QUALITATIVE-DESCRIPTIVE APPROACH

Zulfairanatama, G., \& Hadi, S. (2013). Kecerdasan logika-matematika berdasarkan multiple intelligences terhadap kemampuan matematika siswa SMP di Banjarmasin. EDUMAT: Jurnal Pendidikan Matematika, 1 (1), 18-26. 